\title{
Accounting
}

\section{The effect of BPK audit result on financial performance}

\author{
Miftahul Jannah $^{\mathbf{a}^{*}}$, Azwardi $^{\mathrm{a}}$ and Sa'adah Siddik ${ }^{\mathrm{a}}$
}

\begin{tabular}{|c|c|}
\hline C H R O N I C L E & A B S T R A C T \\
\hline $\begin{array}{l}\text { Article history: } \\
\text { Received: July } 29,2020 \\
\text { Received in revised format: } \\
\text { July } 302020 \\
\text { Accepted: September 7, } 2020 \\
\text { Available online: } \\
\text { September 7, 2020 } \\
\text { Keywords: } \\
\text { Financial performance } \\
\text { BPK audit results } \\
\text { Audit opinion } \\
\text { Audit findings } \\
\text { Local government }\end{array}$ & $\begin{array}{l}\text { The aim of this paper is to identify the influence of BPK audit results on financial performance of } \\
\text { districts / city local government in Sumatera. The technique of collecting data is document analysis } \\
\text { which is distributed among } 390 \text { out of } 492 \text { of the local government financial statements of Sumatra, } \\
\text { Indonesia. The joined data are processed with Eviews } 9.0 \text { using the Random Influence Model (REM). } \\
\text { The results indicate that audit opinion had no significant effect on financial performance of local } \\
\text { government. Moreover, audit findings had no significant effect on the financial performance of local } \\
\text { government. The research results can be beneficial for government as a reference to improve financial } \\
\text { performance. }\end{array}$ \\
\hline
\end{tabular}

\section{Introduction}

Indonesia has been included in the autonomous era where local autonomy provided the policies contained in Law No.22 of 1999 and then revised to Law No. 23 of 2014 about local government. Changes in the management of state finances make people aware that their responsibilities are in the form of aspirations that are useful in improving the management of state and local finances contained in government agencies or local government (Nasution, 2018). To do that, there are all processes, namely through planning, budgeting, budget execution, to financial accountability in the form of financial reports and finally audited (Juweny, 2016). Therefore, to get good governance must refer to PP No. 105 of 2000 which in managing local finance must done orderly, in accordance with the PP namely: influence, efficient and transparent. Therefore, the Government must make a financial report called LKPD (Local Government Financial Report) of course it must be in accordance with applicable law.

BPK in Sumatra is divided in each province respectively. In each province there are LKPD (Local Government Financial Reports) which provide a lot of information. One of the information about opinions, audit findings, financial performance of local government which of course has been audited by the BPK. Each of the BPK audit results fluctuated from year to year. Seen from Table 1. From the data in Table 1, it appears that the results of the BPK audit in the form of opinion are already good in some provinces of Sumatra but the results do not look good in some other regions.

\footnotetext{
* Corresponding author

E-mail address: miftahuljannah.rn04@gmail.com (M. Jannah) 
Table 1

Data on BPK Audit Results in Sumatra

\begin{tabular}{|c|c|c|c|c|c|c|c|c|c|c|}
\hline \multirow{2}{*}{ NO. } & \multirow{2}{*}{ NAME } & \multicolumn{3}{|c|}{ OPINION } & \multicolumn{3}{|c|}{ FINDINGS } & \multicolumn{3}{|c|}{ FINANCIAL PERFORMANCE (\%) } \\
\hline & & 2016 & 2017 & 2018 & 2016 & 2017 & 2018 & 2016 & 2017 & 2018 \\
\hline 1. & Prov. Aceh & WTP & WTP & WTP & 11 & 11 & 18 & 98.51 & 99.32 & 101.49 \\
\hline 2. & Prov. Sumut & WTP & WTP & WTP & 19 & 12 & 10 & 100.34 & 103.83 & 97.43 \\
\hline 3. & Prov. Sumbar & WTP & WTP & WTP & 8 & 8 & 5 & 99.88 & 98.93 & 97.34 \\
\hline 4. & Prov. Riau & WTP & WTP & WTP & 11 & 16 & 21 & 95.90 & 87.27 & 91.79 \\
\hline 5. & Prov. Jambi & WTP & WTP & WTP & 14 & 10 & 14 & 98.86 & 101.84 & 104.71 \\
\hline 6. & Prov. Sumsel & WTP & WTP & WTP & 5 & 13 & 10 & 94.05 & 91.97 & 99.40 \\
\hline 7. & Prov. Bengkulu & WDP & WTP & WTP & 10 & 7 & 9 & 106.16 & 92.99 & 94.97 \\
\hline 8. & Prov. Lampung & WTP & WTP & WTP & 7 & 7 & 11 & 95.93 & 88.20 & 89.45 \\
\hline 9. & Prov. Kep. Babel & WDP & WTP & WTP & 10 & 12 & 10 & 96.66 & 94.33 & 102.81 \\
\hline 10. & Prov. Kep. Riau & WTP & WTP & WTP & 10 & 7 & 6 & 94.45 & 94.63 & 98.72 \\
\hline
\end{tabular}

Source: Processed by the Author, 2020

Masdiantini and Erawati (2016), Purwanto and Harto (2017), report that audit findings did not affect the financial performance of local government. This result is also supported by Agustiawan (2018) in which the results of audit opinions and findings did not influence financial performance. Halimah's research (2017) found that opinions audited by BPK did not influence the financial performance. On the contrary, Handayani (2019) reported that the audit findings did not have any positive influence on financial performance. The conclusions of Lukman's (2019) and Iqbal (2018) did not report any significant relationship between audit findings and financial performance. Others also show the same results that audit opinion has a negative effect on financial performance. With the above data and the inconsistency of the results of previous studies, therefore, this paper is interested in studying the influence of the results of the audit on financial performance in the districts / city government in Sumatra.

\section{Literature Review}

\subsection{The Agency Theory}

The Agency theory is the basic theory in this research. The connection of the impact of BPK audit results with financial performance explains in this agency theory. Described by Jesen and Meckling (1976) this agency theory has a relationship as "Agency relationship as a contract under which one or more people (the principals) engage another person (the agent) to perform some service on their behalf which involves delegating some decision making authority to the agent". The linkage to the agency is where there is an agreement between the individual or group (principal) giving responsibility to the other person (agent) in the form of services to issue the best decision for the principal. Sourced by this agency theory explains that there is a relationship between the government (agent) and the community (principal) due to the contract (contract) established by the community. Not only is it limited to assigning tasks, the principal also continues to monitor and hold accountability for the resources managed in the form of financial statements. The problem arises from differences in ownership owned by the principal and managed by agents (Sudarsana \& Raharjo, 2013). With this mental agent it is possible to achieve some benefits in principal, but in other parts this agent also optimizes its survival. Government is most likely to get information about the resources available in the area in the form of APBD from the public, this is what is known as information asymmetry and problems as agency occur. Because LAKIP / LKPD contains information about performance results, agency problems can be overcome because the community (principal) can directly measure and monitor government performance. From the explanation above, the government as the principal is obliged to make financial reports because agents (the public) need information from the report.

\subsection{Findings Audit}

Findings are a systematic inspection process carried out to find out how actual implementation is determined (Afrian, 2016). Financial performance at the local government will decrease if the audit findings increase (Agustiawan, 2018). The number of findings obtained by the BPK is a grouping of many or at least a finding with reference to the average value of the findings that are available about SPI (Afrian, 2016).

\section{Table 2}

Classification of Audit Findings

\begin{tabular}{lc}
\multicolumn{1}{c}{ Range of Number of Audits } & Classification of Findings \\
\hline$>$ average value of case findings & Many \\
= average value of case findings & Medium \\
< average value of case findings & Little \\
\hline Source: (Masdiantini and Ernawati, 2016) & 2 \\
\hline
\end{tabular}

Source: (Masdiantini and Ernawati, 2016) 


\subsection{Opinion Audit An}

Examination of financial statements conducted by the auditors will result in the form of an audit opinion and the better the opinion obtained, the better the financial performance achieved at the local government (Masdiantini \& Erawati, 2016).

Table 3

Value of Audit

\begin{tabular}{lcc}
\hline & Opinion BPK Audit Opinion on LKPD & Value \\
\hline Reasonable Non Dispensation (WTP) & 5 \\
Reasonable Non Dispensation But There is a Note (WTP-DPP) & \\
Reasonable With Dispensation (WDP) & \\
Unreasonable (TW) & 3 \\
Give No Opinion (TMP)) & 2 \\
\hline
\end{tabular}

Source: (Masdiantini and Ernawati, 2016)

\subsection{Financial Performance of Local Governments}

Financial performance according to Law No. 32 of 2004 is all rights and responsibilities of the region and it can be of cash and items that can be applied as local right of ownership associated with the implementation of these rights and obligations. Financial performance can be reviewed through analysis of local government financial statements (Islami, 2020). In this paper, local government financial performance is measured using the influenceiveness ratio with the following percentage ranges: below $60 \%$ no influencive; $60 \%-80 \%$ less influencive; $80 \%-90 \%$ are quite influencive; $90 \%-100 \%$ influencive and $100 \%$ and above are very influencive. According to Retnowati (2016) and Masdiantini (2016), the following formula is used for measuring the financial performance of local governments.

$$
\text { Financial performance pemerintah }=\frac{\text { Revenue }}{\text { Budget revenues }}
$$

\subsection{Research Model}

$\mathrm{T}$ test is performed for hypothesis testing and random effect model (REM). In random effect model (REM), Equations are formed into models, the equation is:

$Y=\alpha_{0}+\alpha_{1} X_{1}+\alpha_{2} X_{2}+e$,

where:

$X_{1}=$ Audit Opinion, $X_{2}=$ Audit findings, $\mathrm{Y}=$ Financial Performance

\subsection{Hypothesis}

The hypotheses of this paper are as follows,

$\mathrm{H}_{1}$ : Audits opinions have positive effects on financial performance.

$\mathrm{H}_{2}$ : Audits findings have negative effects on financial performance.

\section{Research Methodology}

This paper aims to search for about the effects of audits opinions and findings opinion on financial performance of local government in Sumatera, Indonesia. This paper uses quantitative research approach and some secondary data were obtained from document analysis. The document analysis consists of data from audit opinion and Audit findings. Data of this paper were collected from 130 financial performance of districts / city local government (LKPD) in Sumatera, Indonesia. Eviews 9.0 becomes a statistical procedure for analyzing data in this paper.

\subsection{Sampling Technique}

Samples in this paper are financial performance of districts / city local government (LKPD) in Sumatra, Indonesia taking into consideration that local government was audited by BPK, and do not have LKPDs in complete 3 years from 2016 to 2018 . To determine the sample size there are certain criteria. From these criteria it can be seen that from 492 populations, the sample included only 390 .

\subsection{The Model Feasibility Test Method}

The feasibility test of the model uses 3 approaches, namely: (1 ) Common Effect or Pooled Last Square (PLS ), (2) Fixed Effect Model (FEM), and (3) Random Effect Model (REM). Some of the tests in this paper will be used to choose the best model to use, while the tests are as follows: (1) Chow Test, (2) Hausman Test, and (3) Langrange Multiplier Test. 


\subsection{Classic Assumption Test}

In this paper, the multicollinearity and the heteroscedasticity tests are executed.

\section{Results and Discussion}

\subsection{Results}

Findings of the study consists of the model test, classic assumption test, and the hypothesis test. The test model is carried out through three approaches, namely common influence or polled least square (PLS), fixed effect model (FEM) and common effect model (CEM). Some of the tests in this study will be used to determine the right estimation model to use, while the tests are as follows Chow test, Hausman test, and Lagrange multiplier test. Classical assumption test is a multicollinearity test and a heteroscedasticity test. Hypothesis test discusses the $\mathrm{F}$ test and $\mathrm{t}$ test.

\subsubsection{Model Test}

Table 4

Chow Test

\begin{tabular}{lccc}
\hline Influence Test & Statistics & d.f. & Prob. \\
\hline Cross-section F & 1.711584 & $(129,258)$ & 0.0001 \\
Cross-section Chi-Square & 241.141512 & 129 & 0.0000 \\
\hline
\end{tabular}

To decide the fixed effect model or common effect model that is best used in estimating panel data, we have conducted chow test. The test results of chow test in Table 4 show the value of the probability cross section $F=0.0001<0.05$. F-calculated value $1.711584<$ F Table of 3.019042 and the model of common effect is used in comparison with the fixed influence for estimating panel data.

\section{Table 5}

Hausman Test

\begin{tabular}{llll}
\hline Test summary & Chi-Sq. Statistics & Chi-Sq. d.f. & Prob. \\
\hline Cross-section random & 1.416223 & 2 & 0.4926 \\
\hline
\end{tabular}

Then the Hausman test is a statistical test to choose whether the fixed effect model or the random effect model is the most corresponding for panel data regression. From the results of the Hausman test in Table 5 it can be seen that the probability value is 0.4926 or greater than the alpha 0.05 , then the random effect model is better than the fixed.

\section{Table 6}

Langrange Multiplier

\begin{tabular}{lccc}
\hline Null (no rand. Effect) Alternative & Cross-section One-Sided & Period One-sided & Both \\
\hline Breusch-Pagan & $54.71176(0.0000)$ & $14.71709(0.0001)$ & $69.49885(0.0000)$ \\
Honda & $7.401470(0.0000)$ & $3.836286(0.0001)$ & $7.946294(0.0000)$ \\
King-Wu & $7.401470(0.0000)$ & $3.836286(0.0001)$ & $4.721418(0.0000)$ \\
GHM & - & - & $69.49885(0.0000)$ \\
\hline
\end{tabular}

Lastly Lagrange multiplier given in Table 6 is a test that will decide the random effect model or common effect model corresponding to be used in panel data regression. It can be seen that the value Lagrange multiplier that the significance value is equal to $0.0000<0.05$ which means the right estimation model is the random effect model.

\section{Table 7}

Panel Data Regression Test Results with the Random Effect Model

\begin{tabular}{ccccc}
\hline Variable & Coefficient & Standard Error & t-statistics & Prob. \\
\hline C & 94.87333 & 1.320013 & 71.87301 & 0.0000 \\
X1 & 0.018171 & 0.027966 & 0.649747 & 0.5162 \\
X2 & 0.049708 & 0.032728 & 1.518806 & 0.1296 \\
\hline
\end{tabular}

\subsection{2 classic assumption test}

Table 8 presents the results of multicollinearity between variables. According to table, the multicollinearity test shows that the value of $0.20881<0.90$ which means there is no multicollinearity in the model. Table 9 shows the results of the Heteroscedasticity test. 
Table 8

The results of multicollinearity test

\begin{tabular}{lcc}
\hline & $\mathrm{X} 1$ & $\mathrm{X} 2$ \\
\hline $\mathrm{X} 1$ & 1.000000 & 0.020881 \\
$\mathrm{X} 2$ & 0.020881 & 1.000000 \\
\hline
\end{tabular}

Table 9

The Heteroscedasticity Test

\begin{tabular}{ccccc}
\hline Variable & Coefficient & Std. Error & t-Statistics & Prob. \\
\hline Intercept & 1.095429 & 3.474517 & 0.315275 & 0.7527 \\
X1 & 0.022569 & 0.035340 & 0.638613 & 0.5235 \\
X2 & 0.029576 & 0.017111 & 1.728463 & 0.0847 \\
\hline
\end{tabular}

According to Table 9, the heteroscedasticity shows that all independent variables are statistically significant which means there is no heteroscedasticity. Next, we present the results of some other statistics associated with the proposed study in Table 10 .

\section{Table 10}

The results of $\mathrm{F}$ Test

\begin{tabular}{lll}
\hline R-Squared $=0.007370$ & F-Statistics $=1.436623(0.238994)$ & Durbin-Watson stat $=1.588710$ \\
Adjusted R-Squared $=0.002240$ & Mean dependent var $=57.18096$ & \\
S.E. of regression $=4.375160$ & Sum Square resid $=7407.965$ & \\
\hline
\end{tabular}

Table 10 shows that Durbin-Watson statistics is equal to 1.588710 which means there is no collinearity between the residuals.

In summary, we can conclude that there is no relationship between independent variables; namely, Audit Opinion and Audit findings, and Financial Performance.

\section{Conclusion}

In this paper, we have presented an empirical investigation to study the effects of audit opinion and audit findings on government financial performance. The study collected the necessary information from different regions of Indonesian governmental firms. The results of the regression analysis have indicated that none of two independent variables had any meaningful effect on financial performance. The results of this survey are consistent with the results of Lukman's (2019) and Iqbal (2018) where they reported no significant relationships. Masdiantini and Erawati (2016), Purwanto and Harto (2017) also reported that audit findings did not affect the financial performance of local government. The survey has some limitation which is associated with the region and limitation on the number of sample size. Future studies could extend the independent variables and perform more detailed results.

\section{References}

Afrian, G., Surya, R. A. S., \& Silfi, A. (2016). Pengaruh Karakteristik Pemerintah Daerah, Temuan Audit (Bpk) Dan Leverage Terhadap Kinerja Pemerintah Daerah (Studi Empiris Pemerintah Daerah Kabupaten/kota Di Provinsi Riau) (Doctoral dissertation, Riau University).

Agustiawan, D. (2018). Pengaruh Hasil Pemeriksaan Audit Bpk Terhadap Kinerja Keuangan Pemerintah Daerah Kabupaten Kota Di Indonesia. Skripsi Universitas Lampung

Halimah, N. (2017). PENGARUH OPINI AUDIT, TINDAK LANJUT REKOMENDASI AUDIT DAN INDEKS PERSEPSI KORUPSI TERHADAP KINERJA KEUANGAN PEMERINTAH DAERAH (STUDI EMPIRIS PADA 31 PROVINSI DI INDONESIA) (Doctoral dissertation, Universitas Islam Negeri Sultan Syarif Kasim Riau).

Handayani, K. D. (2019). Pengaruh opini dan temuan audit Badan Pemeriksa Keuangan terhadap kinerja keuangan pemerintah daerah: studi kasus pada Pemerintah Daerah Provinsi Jawa Barat periode 2013-2017.

Parwanto, E., \& Harto, P. (2016). Pengaruh hasil pemeriksaan bpk terhadap kinerja keuangan pemerintah daerah (studi kasus pada pemerintah daerah kabupaten/kota di provinsi jawa tengah) (Doctoral dissertation, Fakultas Ekonomika dan Bisnis).

Iqbal, M. (2018). Pengaruh karakteristik pemerintah daerah, temuan Dan opini audit bpk terhadap kinerja keuangan Pemerintah daerah (studi pada pemerintah kabupaten/kota di provinsi banten).

Islami, A. Y., Edwin, F. \& Riana, M. (2020). Factors influencing the financial performance of south Sumatra Province local government for the period 2012-2016. Journal of Critical Reviews, 7(15), 2115-2124. doi:10.31838/jcr.07.15.282

Jensen, M. C., \& Meckling, W. H. (1976). Theory of the firm: Managerial behavior, agency costs and ownership structure. Journal of financial economics, 3(4), 305-360. 
Juweny, S. (2016). Pengaruh karakteristik Pemerintah Daerah dan Temuan Audit BPK Terhadap Kinerja Pemerintahan Daerah. Tesis Universitas Lampung.

Lukman. (2019). Pengaruh Karakteristik Pemerintah Daerah Dan Temuan Audit Bpk Terhadap Kinerja Keuangan Pemerintah Daerah Kabupaten/Kota. Skripsi Universitas Muhammadiyah Surakarta.

Masdiantini, P. R., \& Erawati, N. M. (2016). Pengaruh ukuran pemerintah daerah, kemakmuran, intergovernmental revenue, temuan dan opini audit BPK pada kinerja keuangan. E-Jurnal Akuntansi Universitas Udayana, 14(2), 1150-1182.

Mappiasse, A. L. (2018). Pengaruh Karakteristik Pemerintah Daerah dan Hasil Pemeriksaan Audit BPK Terhadap Kineja Keuangan. Bongaya Journal of Research in Accounting, 51-55. e-ISSN: 2615-8868

Nasution, D.A.D. (2018). Analisis pengaruh pengelolaan keuangan daerah, akuntabilitas dan transparansi terhadap kinerja keuangan pemerintah. Jurnal Studi Akuntansi \& Keuangan, 2(3), 149-162.

Priyatno, Duwi. 2012. Cara Kilat Belajar Analisis Data dengan SPSS 20. Yogyakarta: ANDI.

Subagyo, A. N. P. (2017). Pengaruh Temuan Audit dan Opini Audit Oleh BPK Terhadap Kinerja Keuangan Pemerintah Daerah Kabupaten/Kota di JawaTimur. SKRIPSI Jurusan Akutansi-Fakultas Ekonomi UM.

Sudarsana \& Raharjo (2013). Pengaruh Karakteristik Pemerintah Daerah dan Temuan Audit BPK Terhadap Kinerja Pemerintah Daerah (Studi Pada Pemerintah Kabupaten/Kota di Indonesia). Skripsi Universitas Diponegoro

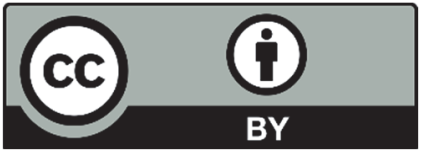

(C) 2020 by the authors; licensee Growing Science, Canada. This is an open access article distributed under the terms and conditions of the Creative Commons Attribution (CC-BY) license (http://creativecommons.org/licenses/by/4.0/). 